ks. Janusz Mieczkowski, Jarosław Superson SAC

\title{
45. Sympozjum Wykładowców Liturgiki w Wydziałach Teologicznych i Wyższych Seminariach Duchownych (Lublin, 8-10 września 2009)
}

W dniach 8-10 września 2009 roku odbyło się w Lublinie Sympozjum Wykładowców Liturgiki pt. Kult Świętych - Nowe „Martyrologium Romanum”. Temat ten został wybrany w związku z planami opublikowania w języku polskim tej księgi liturgicznej. 
Na wstępie ks. prof. dr hab. Helmut Sobeczko, przewodniczący Sekcji Liturgistów Polskich, zaznaczył, że kult świętych jest mało widoczny w celebracjach liturgicznych i pobożności wiernych oraz że mało jest dzisiaj dzieł hagiograficznych.

Pierwszym referentem był ks. dr hab. Andrzej Żądło (Uniwersytet Śląski w Katowicach), który przedstawił Podstawy teologiczne kultu świętych. Swoją wypowiedź zawarł w czterech głównych punktach: obecność i pojęcie kultu świętych w Starym i Nowym Testamencie, świętość Boga i Chrystusa udzielona wszystkim ludziom, sakralny wymiar życia i kultu chrześcijańskiego, rozszerzenie się kultu chrześcijańskiego na świętych. Konkluzją referatu było stwierdzenie, że kult świętych jest objawieniem Boga, wyrazem wiary w orędownictwo świętych i znakiem pragnienia ich naśladowania.

Kolejnym prelegentem był ks. prof. dr hab. Jerzy Stefański (Uniwersytet im. Adama Mickiewicza w Poznaniu) prezentujący temat Prace redakcyjne posoborowego „Martyrologium Romanum”. Jego wypowiedź zbudowana była z trzech części: dlaczego potrzebna była nowa edycja Martyrologium Romanum, jak przeprowadzono redakcję tej księgi oraz co osiągnięto przez jej publikację? Efektem prac posoborowych było to, że w nowym Martyrologium Romanum widzimy już cały Kościół powszechny, ponieważ są w nim święci należący do różnych stanów i grup społecznych oraz pochodzący ze wszystkich kontynentów.

Po tych dwóch referatach wywiązała się dyskusja. Najciekawszymi spostrzeżeniami były: problemy związane z przekładem nazw geograficznych na język polski, pojawienie się nowej edycji Martyrologium Romanum w 2004 roku z nowymi osobami oraz świadomość ogromnej rzeszy świętych męczenników (około 5 milionów), którzy oddali swoje życie za wiarę po II wojnie światowej, a nie są umieszczeni w martyrologium.

Pierwszy dzień obrad zakończył się wspólną celebracją Eucharystii i liturgii godzin w kościele seminaryjnym pod przewodnictwem bpa Stefana Cichego, przewodniczącego Komisji ds. Kultu Bożego i Dyscypliny Sakramentów Episkopatu Polski. Po liturgii uczestnicy zwiedzili Muzeum Archidiecezjalne w Lublinie.

Pierwszym referentem drugiego dnia sympozjum był ks. dr hab. Edwin Mateja (Uniwersytet Opolski), który przedstawił Rozwój kalendarza liturgicznego świętych do reformy papieża Piusa X. Autor zauważył, że w pierwszym tysiącleciu Kościoła nie wypracowano precyzyjnego kalendarza świętych. Kult świętych był związany przede wszystkim z miejscem ich działalności lub pochodzenia. Dzięki zakonom żebraczym cały Kościół przyjął kalendarz, którym posługiwał się Rzym. Średniowiecze przyniosło rozrost kalendarza liturgicznego do zbyt wielkiej liczby świętych, z którym 
to „problemem” nie poradził sobie do końca nawet Sobór Trydencki. Kalendarz potrydencki znów przez wieki był wypełniany nowymi świętymi, którzy zajęli prawie wszystkie dni roku, w związku z czym potrzebna była jego reforma, której podjął się papież Pius X.

W kolejnym referacie przedstawionym przez ks. dra hab. Krzysztofa Koneckiego (Uniwersytet Mikołaja Kopernika w Toruniu) uczestnicy sympozjum zapoznali się z Kryteriami soborowej reformy kalendarza świętych. Prelegent przedstawił cztery kryteria, którymi kierowało się posoborowe konsylium ds. kalendarza liturgicznego. Były to: zmniejszenie liczby świąt dewocyjnych, redukcja obchodów i wspomnień świętych, ustalenie terminów świąt i wspomnień, uniwersalizm kalendarza świętych (geograficzny, historyczny, społeczny). Nie wszystkie te kryteria udało się zastosować w kalendarzu ogólnym z 1969 roku (np. wśród wspomnień obowiązkowych nie było żadnego Polaka! Pierwszym z nich był dopiero św. Stanisław, biskup i męczennik, wpisany do niego dopiero w 1979 roku).

Przedpołudniową sesję zakończyła dyskusja poświęcona kultowi głównych patronów Polski (do końca XIX wieku pojawiły się imiona aż 53 świętych i błogosławionych).

Po referacie wszyscy udali się do kościoła katedralnego, gdzie celebrowali Eucharystię, której przewodniczył metropolita lubelski bp prof. dr hab. Józef Życiński.

Popołudnie drugiego dnia zostało poświęcone na zwiedzanie pałacu w Kozłówce i sanktuarium św. Anny w Lubartowie.

Ostatni dzień sympozjum wypełniły sprawozdania z poszczególnych ośrodków naukowych w Polsce, relacje o nowych pracach habilitacyjnych i profesorskich z liturgiki, dyskusja na temat obecności haseł liturgicznych w Encyklopedii katolickiej wydawanej przez Katolicki Uniwersytet Lubelski oraz informacje dotyczące działalności Komisji ds. Kultu Bożego i Dyscypliny Sakramentów Episkopatu Polski.

Sympozjum zakończyło się zaproszeniem wszystkich uczestników na kolejne spotkanie, które odbędzie się w 2010 roku w Katowicach. 